\title{
torso-like encodes the localized determinant of Drosophila terminal pattern formation
}

\author{
Smita Savant-Bhonsale and Denise J. Montell \\ Department of Biological Chemistry, Johns Hopkins University School of Medicine, Baltimore, Maryland 21205 USA
}

\begin{abstract}
Differentiation of the anterior and posterior poles of the Drosophila embryo requires seven maternally expressed genes including torso-like (ts $I$ ) and torso (tor). The tor gene encodes a receptor tyrosine kinase that is expressed throughout the embryo but is activated specifically at the poles. Genetic mosaic analysis has shown that $t s l$ is required during oogenesis in follicle cells at each end of the oocyte. We cloned the tsl locus and showed that it was expressed specifically in follicle cells at the anterior and posterior ends of the oocyte. $t s l$ encodes a novel protein with a putative amino-terminal signal sequence. Ectopic expression of $t s l$ produced embryos with a phenotype similar to that resulting from constitutively active Tor alleles. These results suggest that localized TSL controls the localized activation of TOR.
\end{abstract}

[Key Words: torso-like gene; Drosophila embryo; pattern formation; oogenesis; ectopic expression]

Received September 13, 1993; revised version accepted October 19, 1993.

Anterior-posterior pattern formation in Drosophila depends on spatially localized gene products deposited in the egg during oogenesis (for review, see St. Johnston and Nüsslein-Volhard 1992). Three distinct determinant systems are required for specification of the anterior-posterior axis, and they are referred to as the anterior, posterior, and terminal systems. The anterior and posterior systems determine the segmented regions of the head; the thorax and the abdomen and rely on localization of specific mRNAs to the anterior and posterior ends of the embryo, respectively. Proper development of the nonsegmented head and tail (terminal) regions of the Drosophila embryo depends on the action of seven maternal effect genes: torso [tor (Schupbach and Wieschaus 1986)]; torso-like [tsl (Stevens et al. 1990)]; fs(1) Nasrat [fs(1)N (Degelmann et al. 1986)]; fs(1)polehole [fs(1)ph (Perrimon et al. 1986)]; trunk [trk (Schupbach and Wieschaus 1986)]; corkscrew [csw (Perkins et al. 1992)]; and 1(1)polehole [1(1)ph (Perrimon et al. 1985)]. Recessive mutations in any of these genes give rise to the same phenotype, loss of the anterior portion of the head, and of all structures posterior to and including the eighth abdominal segment.

A key step in terminal patterning is the localized activation of the receptor tyrosine kinase (RTK) encoded by the tor locus (Sprenger et al. 1989). This receptor is found uniformly distributed throughout the plasma membrane of the oocyte and early embryo (Casanova and Struhl 1989); however, activation of the receptor is normally restricted to the extreme anterior and posterior ends. Tor gain-of-function mutations cause the production of constitutively active receptor leading to a disruption of seg- mentation in the trunk region of the embryo and ectopic production of terminal structures (Klingler et al. 1988; Strecker et al. 1989; Sprenger and Nüsslein-Volhard 1993). Epistasis analysis with Tor gain-of-function mutations has revealed that $l(1) p h$ (also known as D-raf) and csw act downstream of the receptor, whereas the other maternal effect loci act before activation of the receptor (Ambrosio et al. 1989; Perkins et al. 1992).

An important question that remains is how localized activation of the TOR receptor is achieved. The $t s l$ gene is a particularly good candidate for encoding a localized signal leading to activation of the TOR receptor. The requirement for $t s l^{+}$function has been shown by mosaic analysis to be restricted to a few follicle cells at each end of the egg chamber during oogenesis (Stevens et al. 1990), whereas the other maternal effect genes are required in the germ line (Perrimon and Gans 1983; Schupbach and Wieschaus 1986; Perkins et al. 1992). tsl could encode an extracellular protein, either the ligand for the TOR receptor or some product involved in the production of an active TOR ligand. Alternatively, $t s l$ could encode a regulatory protein controlling the expression of such a signal.

In this paper we describe the isolation and characterization of the $t s l$ gene. We report that expression of $t s l$ is normally restricted to a subset of follicle cells at each end of the egg chamber. Ectopic expression of tsl caused patterning defects similar to those of dominant tor alleles, indicating that the localized expression of $t s l$ is critical for proper terminal patterning. Sequence analysis revealed an amino-terminal signal sequence, suggesting that the TSL protein is a secreted product. 


\section{Results}

\section{Identification of a P-element insertion allele of tsl}

In studying the migration and function of the specialized follicle cells known as the border cells (King 1970; Montell el al. 1992), we screened 7800 single P-element enhancer trap insertions on the second and third chromosomes (Karpen and Spradling 1992) for their $\beta$-galactosidase staining patterns in the ovary and for lethal and female sterile phenotypes (Montell et al. 1992). One line displayed a weakly fertile phenotype and specific $\beta$-galactosidase expression in the border cells and a group of posterior follicle cells (Fig. 1). Approximately $90 \%$ of eggs laid by homozygous PZ0617 females failed to hatch into larvae.

The single P-element insertion in this line was mapped to $93 \mathrm{~F}$ on the polytene chromosomes by in situ hybridization (data not shown), the same location as the tsl locus (Stevens et al. 1990). Because of this chromosomal location and the female sterile phenotype, we tested females heterozygous for the P-element insertion and a point mutation in the $t s I$ locus for complementation and found that they were also weakly fertile. Based on this complementation data and the excision data described below, we refer to the P-element insertion as a new allele of $t s 1, t s 1^{0617}$ (Table 1).

To generate stronger alleles and to test whether the apparent $t s l$ mutation was attributable to insertion of the P-element, we remobilized the P-element using a standard excision protocol (Cohen et al. 1992). The weakly fertile phenotype completely reverted to wild-type in $6 / 16$ independent rosy ${ }^{-}$lines, indicating that the mutation was attributable to the P-element insertion and not to a second mutation elsewhere on the chromosome. In addition, one excision line, $t s 1^{0617 e 8,}$ was completely sterile both when homozygous and when heterozygous

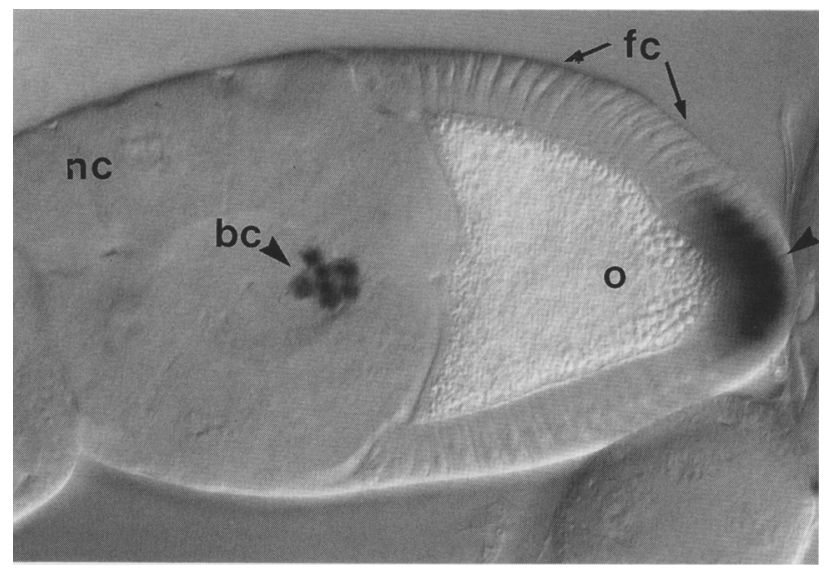

Figure 1. $\beta$-Galactosidase expression from the enhancer trap. Stage 9 egg chamber from a PZ0617 female, stained for $\beta$-galactosidase activity. Migrating border cells (bc, arrowhead) and posterior follicle cells (arrowhead) stain specifically. Nurse cells (nc), oocyte (o), and columnar follicle cells $(\mathrm{fc})$ are indicated. Anterior is to the left.
Table 1. Complementation analysis of tsl alleles

\begin{tabular}{|c|c|c|c|c|}
\hline & $t s 1^{691}$ & $t s 1^{0617}$ & $t s 1^{0617 e 8 b}$ & $t s 1^{0617 e 1}$ \\
\hline$t s 1^{691}$ & $\begin{array}{l}\text { female } \\
\text { sterile }\end{array}$ & $\begin{array}{l}\text { weakly } \\
\text { fertile }\end{array}$ & $\begin{array}{l}\text { female } \\
\text { sterile }\end{array}$ & N.T. \\
\hline$t s 1^{0617}$ & & $\begin{array}{c}\text { weakly } \\
\text { fertile }\end{array}$ & $\begin{array}{c}\text { weakly } \\
\text { fertile }\end{array}$ & fertile \\
\hline$t s 1^{0617 e 8 b}$ & & & $\begin{array}{c}\text { female } \\
\text { sterile }\end{array}$ & N.T. \\
\hline$t s I^{0617 e 1}$ & & & & fertile \\
\hline
\end{tabular}

(N.T.) not tested. $t s 1^{0617 e 1}$ was representative of six lines that reverted to wild type.

with a tsl point mutation (Table 1). Furthermore, the cuticularized embryos all displayed a typical "terminal" phenotype (Fig. 2), including head and tail deletions. Taken together, these data indicated that $t s 1^{0617}$ was a hypomorphic allele of the tsl locus.

\section{Identification of the tsl gene}

DNA flanking the $t s 1^{0617}$ element was cloned, and the site of P-element insertion determined (see Materials and methods|. A transcript map for the region was generated by using subfragments of the $\lambda$ phage clone to probe Northern blots containing poly $(\mathrm{A})^{+}$RNA from ovaries and embryos (Fig. 3B). Probes from one side of the P-element hybridized to a 7-kb RNA present in embryos but not in ovaries, whereas probes from the other side of the P-element hybridized to a 1.9-kb RNA present in both ovaries and embryos (Fig. 3C). Furthermore, the 1.9$\mathrm{kb}$ mRNA appeared to be reduced in concentration in ovaries from $t s 1^{0617}$ mutant females (Fig. 3B). Because the

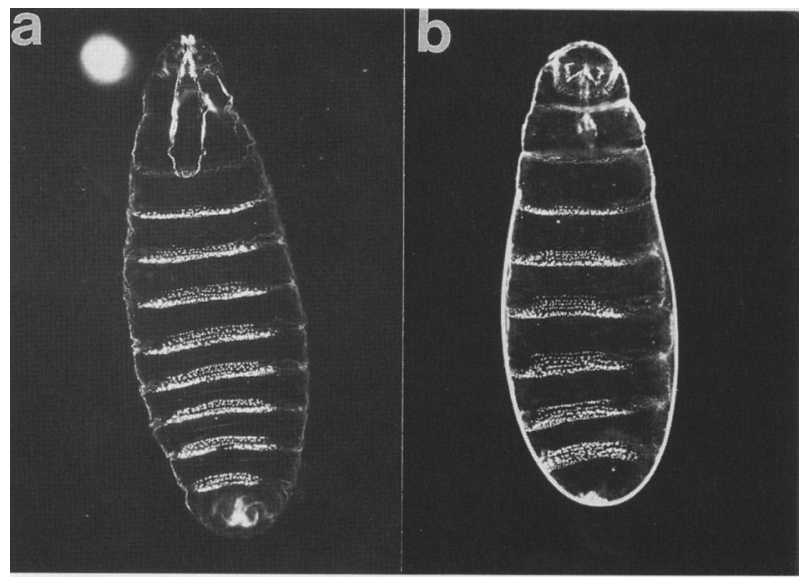

Figure 2. Terminal class phenotype of $t s 1^{0617 e 8}$ excision allele. Dark-field micrographs of cuticle preparations of embryos produced by wild-type $(a)$ and heterozygous $t s 1^{0617 e 8 b} / t s 1^{691}(b)$ showing deletions of terminal structures. Eight ventral denticle belts, a well-formed head skeleton, and posterior spiracles can be seen in $a$. In $b$ the head skeleton is reduced, only 6 ventral denticle belts are clearly distinguished, and posterior spiracles are missing. 
Figure 3. Transcript map for the $t s l$ locus. (A) Schematic representation of genomic DNA surrounding the site of $t s 1^{0617}$ P-element insertion. The P-element is not drawn to scale. EcoRI (R), SalI (S), and Asp718 (A) sites are indicated, as well as the fragment that was used for transformation rescue. $(B)$ Northern blots of embryonic (E) and ovarian (O) poly $(\mathrm{A})^{+}$RNA using the probes indicated in $A .(C)$ Northern blots comparing transcript levels in ovary poly $(\mathrm{A})^{+}$RNA from wild-type (lane 1), homozygous $t s l^{0617}$ (lane 2), and homozygous tsl $1^{691}$ (lane 3) females. The blot was reprobed with rp49/not shown) and tubulin cDNAs to ensure equal loading.
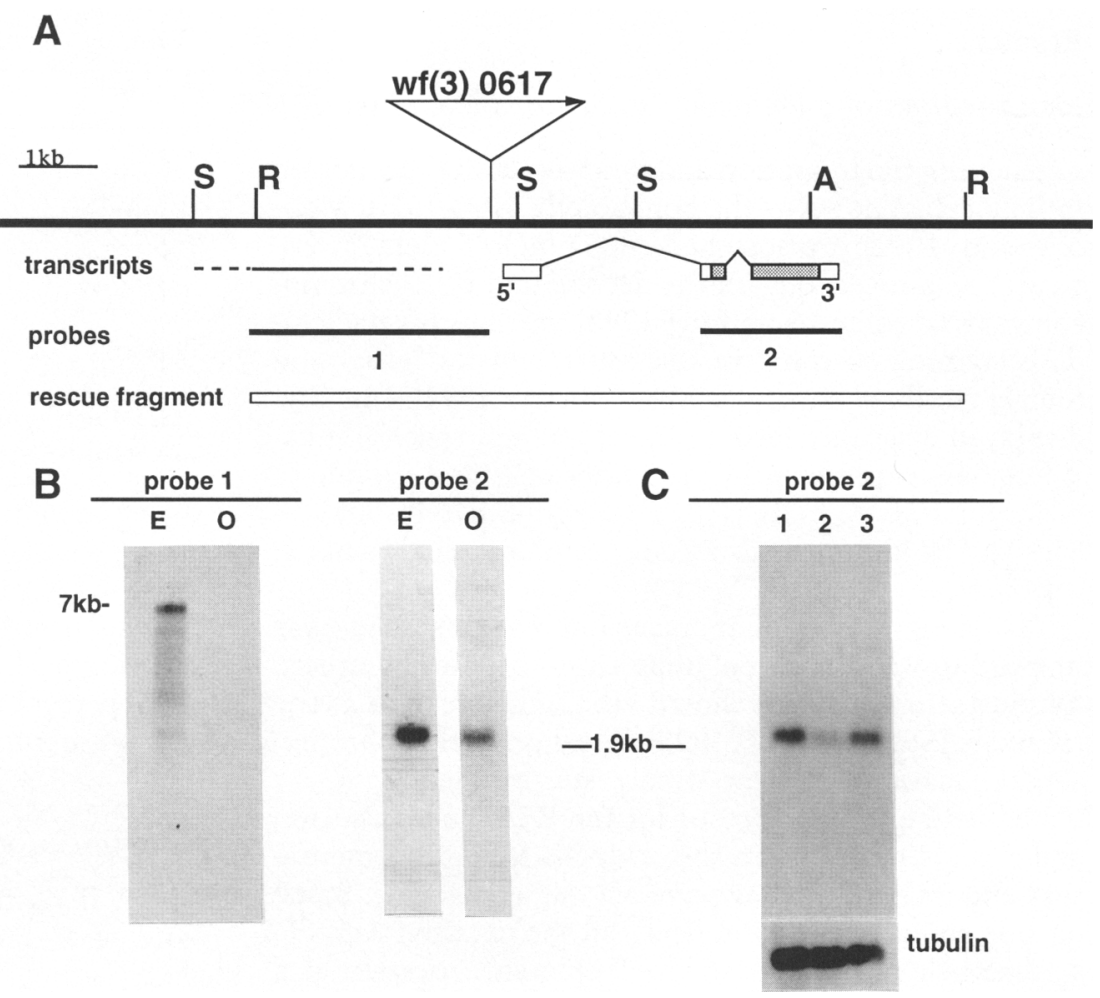

$t s l$ gene is required in ovaries, we focused on the $1.9-\mathrm{kb}$ transcript as the best candidate for $t s l$.

To investigate the spatial pattern of expression of the 1.9-kb mRNA, several cDNA clones were isolated. Single-stranded, digoxygenin-labeled probes were made and used for in situ hybridization to ovaries. The result is shown in Figure 4. Specific hybridization to border cells

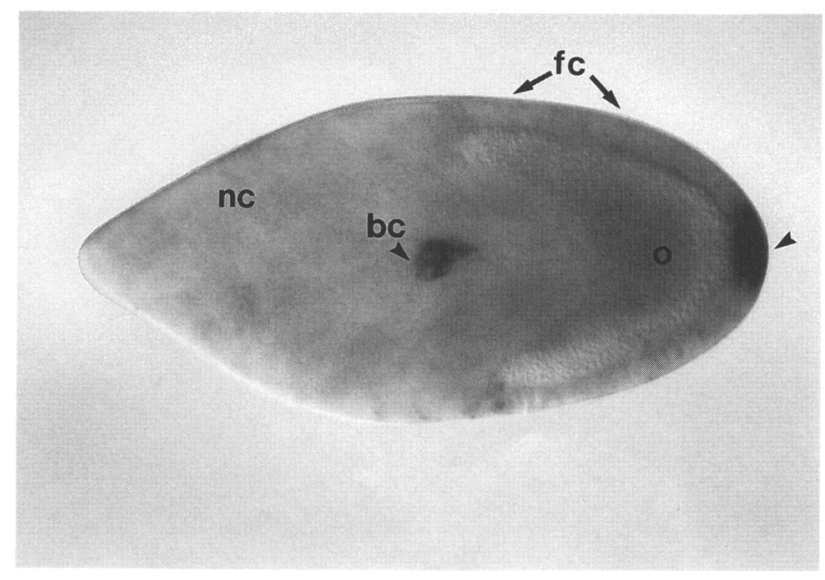

Figure 4. In situ hybridization. Normarski optics micrograph of a stage $10 \mathrm{~A}$ egg chamber. A putative tsl cDNA was labeled with digoxygenin and hybridized to egg chambers treated as described in Materials and methods. Border cells (bc, arrowhead) and posterior follicle cells (arrowhead) are specifically labeled. The nurse cell cluster (nc), columnar follicle cells (fc), and oocyte $(0)$ are indicated. and posterior follicle cells was seen with one strand only, in a pattern closely resembling the $\beta$-galactosidase expression from $t s l^{0617}$ (Fig. 1) and closely resembling that predicted for the $t s l$ gene based on mosaic analysis (Stevens et al. 1990). Expression was first detected quite early in oogenesis, at stage 3 (for staging, see King 1970), in just two follicle cells at each end of the egg chamber (not shown). And at later stages, a larger number of anterior follicle cells, namely the centripetal follicle cells, were also labeled (not shown).

To test for $t s l$ function, the 10-kb EcoRI genomic DNA fragment, which truncates the neighboring embryonic transcript but includes all transcribed sequences from the $t s l$ gene, was cloned into a P-element transformation vector. This DNA was injected into embryos, and six independent germ-line transformants were obtained. The presence of a single copy of the transgene was sufficient to rescue the strongest $t s l$ allele to fertility, providing strong evidence that the $1.9-\mathrm{kb}$ transcript corresponded to tsl.

The nucleotide and deduced amino acid sequences of a putative full-length tsl cDNA are shown in Figure 5. Conceptual translation revealed a single long open reading frame of 353 amino acids with good Drosophila codon usage (not shown). Amino acids 1-22 were found to have a high probability of forming a signal sequence as predicted by the algorithm of von Heijne (1986). All of the features of a signal sequence were present, including a positively charged amino acid following the methionine, a hydrophobic sequence long enough to span the bilayer, followed by a more polar sequence and a poten- 


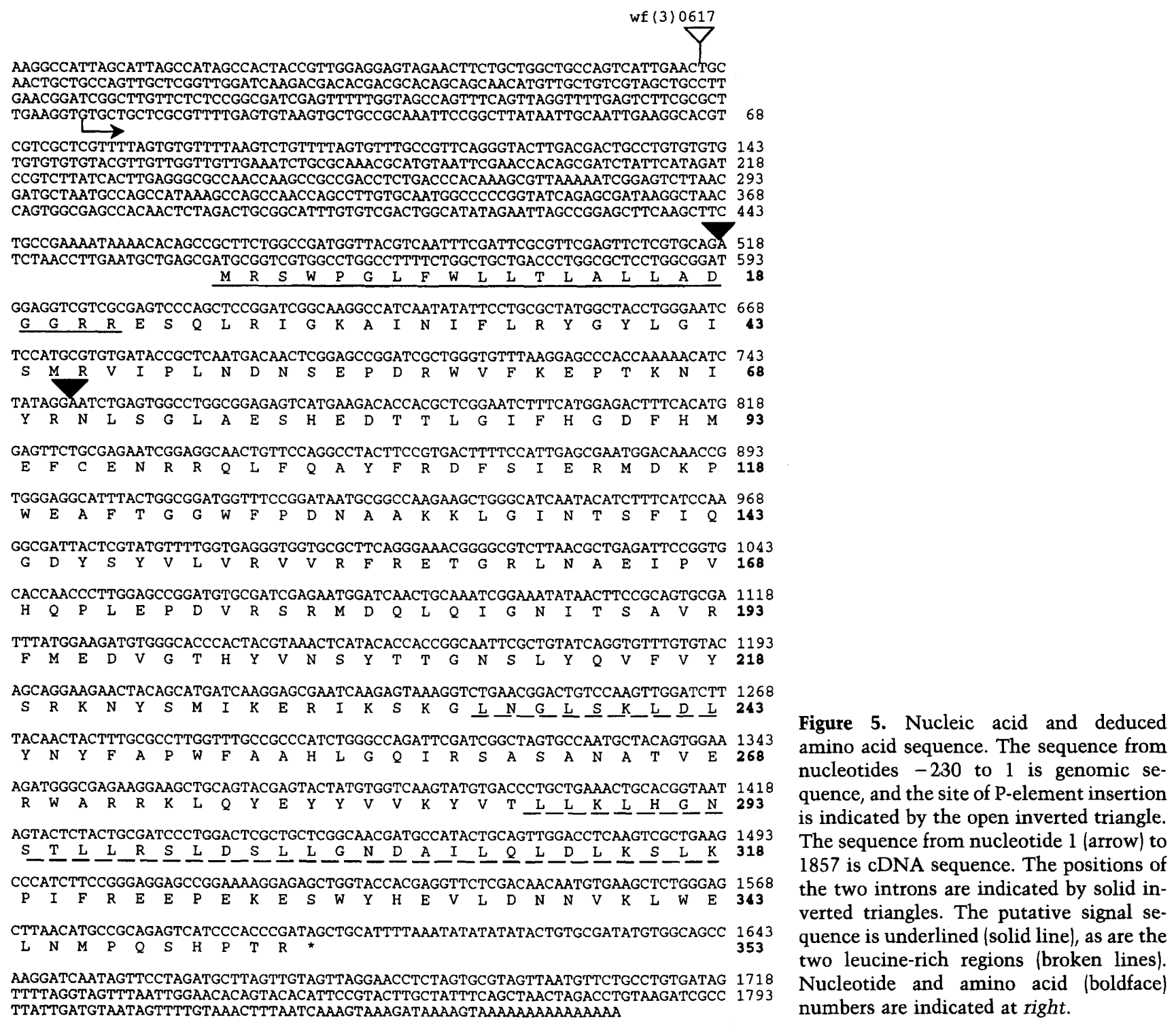

tial cleavage site. Hydrophobicity analysis failed to reveal any additional potential membrane-spanning regions (data not shown). Taken together, these data indicated that the product was likely to be secreted. When compared with known sequences in the GenBank data base using the BLAST program, no significant homology to other proteins was detected. However, we have observed two leucine-rich domains (40\% leucine) near the carboxyl terminus with a weak resemblance to the leucine-rich repeats found in Toll, chaoptin, and other proteins. Comparison of the cDNA and genomic sequences revealed two introns, which are indicated on the transcript map.

Five ethylmethane sulfonate (EMS)-induced $t s l$ alleles have been reported previously (Stevens et al. 1990). They have been ordered in an allelic series of decreasing severity such that $174=691>146>035>135$. To determine the lesions in these mutant alleles, we amplified geno- mic DNA corresponding to the tsl-coding region from each mutant, using the PCR, and sequenced the products directly. A single nucleotide change causing an amino acid substitution was found in each case as indicated in Figure 6. Two of the alleles, 174 and 146, had similar substitutions in that they changed a tyrosine residue to

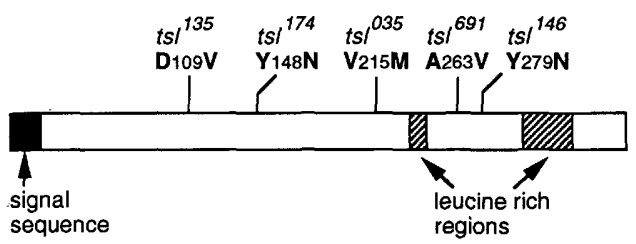

Figure 6. Schematic diagram of the deduced TSL protein. Amino acid substitutions found in the five EMS-induced mutations are indicated (for details, see text). 
an asparagine, and the mutated tryosines occurred within similar sequences (YSYVLVRVV and YEYYVVKYV|. No other nucleotide differences were observed except in $t s 1^{691}$, where a silent $\mathrm{T}$-C was observed in codon 248 , which encodes a proline. The molecular lesion in the $t s 1^{0617 e 8}$ excision line, which had a stronger phenotype than the original $t s 1^{0617}$ insertion /see Table 1), was determined by probing genomic Southern blots with probes from each end of the P-element /data not shown|. We found that only internal P-element sequences and no flanking DNA had been deleted.

\section{Ectopic expression of tsl}

If the normal pattern of $t s l$ expression were crucial for providing spatially restricted activation of the TOR receptor, uniform tsl expression would be expected to cause uniform TOR activation and a phenotype similar to that observed in mutants with constitutive activation of the TOR receptor. Because the heat shock promoter drives uniformly high levels of expression in all follicle cells (Xu and Rubin 1993), one of the putative full-length cDNAs was cloned into a P-element transformation vector behind the hsp70 heat-inducible promoter. This DNA was injected into embryos, and eight independent germ-line transformants were obtained. We found that when a single $1-\mathrm{hr}$ heat shock was administered to females bearing the hs-tsl construct, $50-60 \%$ of the cuticularized embryos that developed displayed a phenotype similar to that of the dominant Tor allele $\operatorname{Tor}^{R L 3}$ (Fig. 7). The characteristics of the $\operatorname{Tor}^{R L 3}$ phenotype are that abdominal segmentation is suppressed and/or disrupted, ectopic filzkörper material and/or mouth parts are occasionally produced, and the embryos are about half the
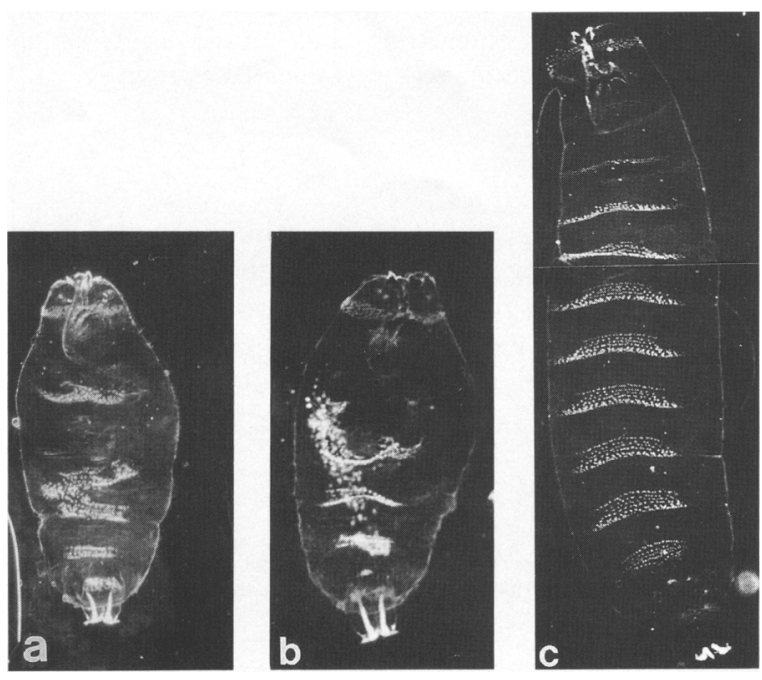

Figure 7. Ectopic expression of $t s 1$. Dark-field micrographs of cuticle preparations from $\operatorname{Tor}^{R L 3}$ gain-of-function allele $(a)$, hs$t s l\langle b|$, and $w^{1118}$ heat-shocked control $(c)$. Note the similarity between $a$ and $b$ : Embryos are shorter than wild type, and abdominal segmentation is severely disrupted; however, the termini remain relatively normal. length of wild-type embryos. Embryos from females carrying the hs-tsl construct were short and had suppressed and disrupted abdominal segmentation; however, we did not observe ectopic terminal structures. These phenotypes were dependent on the hs-tsl construct and were not artifacts of the heat shock treatment because we did not observe such defects in embryos derived from $w^{1118}$ females that had been treated similarly.

\section{Discussion}

An early event in terminal patterning is the localized activation of the TOR RTK at the two poles of the blastoderm. The genes acting downstream of tor include Ras1 (Lu et al. 1993), the Raf serine-threonine kinase (Nishida et al. 1988; Ambrosio et al. 1989; Sprenger et al. 1993/, and a tyrosine phosphatase encoded by the csw locus (Perkins et al. 1992). This signal transduction cascade ultimately results in the spatially restricted expression of transcription factors encoded by the tailless and huckebein loci. A key question that remains in understanding terminal pattern formation is how the TOR receptor becomes activated only at the two poles. Immunocytochemistry, as well as functional studies, has shown that the receptor is present throughout the plasma membrane surrounding the embryo (Casanova and Struhl 1989/ yet activated only at the two ends (Casanova and Struhl 1993; Sprenger and Nüsslein-Volhard 1993). Our results indicate that $t s l$ expression is restricted to follicle cells at each end of the oocyte during oogenesis, that the product is likely to be a secreted protein, and that ectopic tsl expression is sufficient to cause ubiquitous TOR activation.

\section{Evidence that the 1.9-kb transcript corresponds to tsl}

Several lines of evidence indicate that the 1.9 -kb transcript that we identified was the product of the $t s l$ locus. First, we rescued the mutant phenotype by germ-line transformation. Second, the restricted spatial expression pattern of this transcript correlated well with that predicted from mosaic analysis (see below). Third, we have detected changes in the coding region in each of five EMS-induced $t s l$ alleles and a decrease in the level of mRNA in the weaker, P-element-induced allele. Finally, we obtained the predicted gain-of-function phenotype by expressing the cDNA ectopically.

\section{Spatially restricted tsl expression is critical for terminal patterning}

$t s l$ is the only maternal effect, terminal class gene identified to date with a function that is required in the somatic follicle cells and not in the germ line (St. Johnston and Nüsslein-Volhard 1992). Furthermore, mosaic analysis demonstrated that $t s l$ function is required only in follicle cells at the anterior and posterior poles of the oocyte, rather than in all of the follicle cells (Stevens et al. 1990). On the basis of the expression of the lacZ reporter gene in the $t s l$ enhancer trap allele and in situ 
hybridization of the cDNA to ovaries, we found tsl expression to be restricted to follicle cells at the anterior and posterior poles of the oocyte. Thus, the expression pattern and genetic requirement corresponded closely.

We also showed that ectopic expression of $t s 1$ in all follicle cells was sufficient to cause the disruption of abdominal segmentation that is characteristic of Tor gain-of-function mutations. We concluded that ectopic tsl expression was sufficient to cause ubiquitous TOR activation, suggesting that all of the other components required for TOR activation must be present all around the embryo. Therefore TSL is the only localized signal in terminal pattern formation prior to TOR activation.

\section{The TSL product}

The most striking feature of the TSL-deduced amino acid sequence was the presence of a putative amino-terminal signal sequence. Because $t s l$ function is required in the follicle cells, it has been proposed previously that $t s l$ might encode a secreted protein deposited into the perivitelline space, or a transcription factor or some other type of regulatory protein involved in the production of a secreted signal (Stevens et al. 1990; St. Johnston and Nüsslein-Volhard 1992). Our results indicate that $t s 1$ does not encode a transcriptional or post-transcriptional regulatory protein. Rather, the presence of a putative signal sequence strongly supports the model that the TSL product is secreted into the vitelline membrane or perivitelline space and, therefore, that TSL participates directly in the signaling pathway.

Although sequence analysis did not reveal significant homologies with proteins of known biochemical function, two regions of leucine-rich sequence with some similarity to the leucine-rich repeats found in Toll, chaoptin, and connectin (Nose et al. 1992) were observed in the TSL sequence. The precise function of such repeats has not been characterized; however, they have been implicated in mediating protein-protein and protein-lipid interactions (Krantz et al. 1991).

All of the EMS-induced alleles were characterized by single amino acid substitutions; thus, it is possible that even the strongest alleles are not null mutations. Because all of the $t s 1$ alleles were recovered in screens for female sterile mutants, it is possible that the null phenotype is actually lethality. Consistent with this idea, we have recovered lethal excision lines from the $t s 1^{0617}$ P-element insertion (C. Andrews and D. Montell, unpubl.); however, it is not yet clear that the lethality is attributable to loss of $t s l$ function. The observations that two of the stronger mutations resulted in replacement of tyrosine residues by asparagine residues and that the mutated tyrosines occurred within somewhat similar sequences suggest that these two motifs serve similar functions. It was surprising to find that the relatively conservative replacement of alanine by valine in $t s l^{691}$ results in a strong female sterile phenotype. However an alanine-to-valine substitution in the superoxide dysmutase gene has recently been characterized, which also leads to a strong mutant phenotype (Deng et al. 1993).

\section{The role of tsl in terminal patterning}

Whereas tsl appears to encode the localized signal for TOR activation, a remaining question is whether TSL is the TOR ligand or whether TSL somehow converts a uniformly distributed, inactive ligand precursor into an active form. The active TOR ligand has been demonstrated to have three important characteristics: It is present in limiting amount; it is spatially localized; and it is freely diffusible (Casanova and Struhl 1993; Sprenger and Nüsslein-Volhard 1993). Although TSL is very likely to be spatially localized based on the expression pattern of the mRNA, TSL is unlikely to be freely diffusible. This is because TSL is made during oogenesis and must be kept from diffusing for hours (or even days if females are holding their eggs), until after fertilization when the ligand acts (Sprenger and Nüsslein-Volhard 1993).

Three additional genes, namely trk, $f_{S}(1) N$, and $f_{s}(1) p h$, are required for normal activation of TORSO. $f_{s}(1) p h$ and $f_{s}(1) N$ are candidates for genes with products that might be involved in anchoring TSL to the vitelline membrane. Females homozygous for most alleles of these loci produce eggs that collapse, indicating a role for these gene products in maintaining eggshell integrity (Degelmann et al. 1990). trk mutants, on the other hand, produce embryos with only terminal patterning defects. It has been suggested that the TRK protein may be a secreted, inactive ligand for TOR (Casanova and Struhl 1993). If so, this would suggest that TSL is more likely to be involved in converting inactive TRK into active TRK. This model could explain why ectopic terminal structures were not observed in hs-tsl embryos. Ectopic expression of TSL, while producing ectopic active TRK and disrupted abdominal segmentation, might not produce as high a level of TOR activity as mutations in TOR itself, if TRK were the product that was limiting in amount.

\section{Materials and methods}

Fly stocks and isolation of P-element tsl allele

EMS-induced tsl mutant alleles were gifts from Dr. L. Stevens (Albert Einstein University, New York). The $t s 1^{0617}$ allele was obtained in an enhancer trap screen (Karpen and Spradling 1992) using the PlacZ element described in Mlodzik et al. (1990).

\section{Cloning}

DNA flanking the $t s 1^{0617}$ P-element was cloned by making a library in $\lambda$ ZAP (Stratagene), following complete digestion of $t s 1^{0617}$ genomic DNA with EcoRI, and screening with a P-element-specific probe. Flanking sequence $(3 \mathrm{~kb})$ was recovered and used as a probe to isolate a $\lambda$ phage clone from a wild-type genomic library. The site of P-element insertion was determined by comparing the restriction map of the $3-\mathrm{kb}$ flanking DNA with that of the wild-type phage clone and by genomic Southern blotting using P-element and flanking DNA probes on blots containing DNA from $t s 1^{0617}$ and wild-type flies. The site was subsequently confirmed by DNA sequencing. Embryonic and ovarian cDNA libraries [gifts of S. Hawley /University of California, Davis) and A. Spradling (Carnegie Institute of Wash- 
ington, Baltimore, $\mathrm{MD}$ |, respectively] were screened with the 4-kb EcoRI-Sall genomic fragment. No clones were obtained from the ovarian library, however, one clone was obtained from the embryonic library. This clone was later determined by sequencing to be a genomic DNA fragment spanning $1.6 \mathrm{~kb}$ of transcribed sequence, including the 330-bp intron within the coding sequence. This clone was used to isolate several cDNAs from a 9- to 12-hr embryonic library la generous gift from K. Zinn, California Institute of Technology, Pasadena), including several that were $1.9 \mathrm{~kb}$ in length.

\section{$\beta$-Galactosidase staining and in situ hybridization in ovaries}

Staining for $\beta$-galactosidase activity was carried out as described (Montell et al. 1992). For in situ hybridizations, egg chambers were dissected in Ringer's solution and fixed in $4 \%$ paraformaldehyde (Polysciences, E.M. grade) in $1 \times$ PBS (PP) for $20 \mathrm{~min}$. Following three washes in $1 \times$ PBS with $0.1 \%$ Tween 20 (Sigma, $\mathrm{PBT}$ ) for $5 \mathrm{~min}$ each, egg chambers were digested with $100 \mu \mathrm{g} /$ $\mathrm{ml}$ of proteinase $\mathrm{K}$ (Boerhinger Mannheim) in PBT for $1 \mathrm{hr}$ at room temperature, rinsed once with $0.2 \%$ glycine in $\mathrm{PBT}$, and refixed for $20 \mathrm{~min}$ in $\mathrm{PP}$; they were then washed three times for 20 min each in PBT alone. Egg chambers were then treated with $90 \%$ methanol $/ 10 \% 0.2 \mathrm{M}$ EGTA for $1 \mathrm{hr}$ at $-20^{\circ} \mathrm{C}$, washed with PBT three times for $20 \mathrm{~min}$ each, and equilibrated in hybridization buffer $150 \%$ formamide, $5 \times \mathrm{SSC}, 100 \mu \mathrm{g} / \mathrm{ml}$ of salmon sperm DNA, $50 \mu \mathrm{g} / \mathrm{ml}$ of heparin, $50 \mu \mathrm{g} / \mathrm{ml}$ of tRNA, $0.1 \%$ Tween 20 ). Egg chambers were prehybridized in the same solution at $42^{\circ} \mathrm{C}$ before the probe was added and incubated overnight. Single-stranded, digoxygenin-labeled probes were made by asymmetric PCR. The PCR reaction contained $0.1 \mu \mathrm{g}$ of plasmid DNA, $0.05 \mathrm{M} \mathrm{KCl}, 0.01 \mathrm{M}$ Tris- $\mathrm{HCl}(\mathrm{pH} 8.3), 1.5 \mathrm{~mm} \mathrm{MgCl}$, $0.001 \%$ gelatin, $0.2 \mathrm{~mm}$ each dATP, dCTP, and dGTP, $0.13 \mathrm{~mm}$ dTTP, 0.075 mM digoxygenin-11-dUTP (Boerhinger Mannheim), $150 \mathrm{ng}$ KS or SK primer, and 2 units of AmpliTaq polymerase (Cetus Corporation). Forty microlitersof mineral oil was added and the reaction was subjected to 35 cycles of the following temperature paradigm: $95^{\circ} \mathrm{C}$ for $45 \mathrm{~min} ; 55^{\circ} \mathrm{C}$ for $30 \mathrm{~min}$, $72^{\circ} \mathrm{C}$ for $1 \mathrm{~min}$ and $30 \mathrm{sec}$. The product was ethanol precipitated and resuspended in hybridization buffer, boiled for $1 \mathrm{hr}$ to reduced the size of the probe, chilled, and added to egg chambers. Subsequent washing and developing of the reaction was carried out as described (Tautz and Pfeifle 1989).

\section{Plasmid construction and germ-line transformation}

The 1.9-kb tsl cDNA insert was amplified from phage DNA using PCR ( $\lambda$ gt 11 primers: 5'-AGCGACCGGCGCTCAGCTGGAATTC-3' and ' ${ }^{\prime}$-GGAGCCCGTCAGTATCGGCGGAATTC-3') and cloned into the EcoRI site of pBluescript (SK +, Stragtagene). The hs-tsl construct was made by subcloning the same 1.9-kb EcoRI fragment into pCaSpeR-hs (a gift from C. Thummel, University of Utah, Salt Lake Cityl. The rescue construct was made by subcloning the $10-\mathrm{kb}$ EcoRI genomic fragment containing the tsl gene into pCaSpeR-1 (a gift from C. Thummel) to create pCaSpeR-Gtsl. Plasmids pCaSpeR-hstsl $(0.4 \mathrm{mg} / \mathrm{ml})$ and $\mathrm{pCaSpeR}-\mathrm{Gtsl}(0.4 \mathrm{mg} / \mathrm{ml})$ were microinjected into $w^{1118}$ embryos, along with the helper plasmid $\mathrm{p} \pi 25.2 \mathrm{wc}$ $(0.1 \mathrm{mg} / \mathrm{ml})$, following a standard P-element mediated germline transformation protocol (Rubin and Spradling 1982; Grigiatti et al. 1986). In subsequent generations progeny expressing the $w^{+}$gene were selected as transformants. Insertions were mapped to a chromosome by segregation analysis, balanced, and underwent homozygosis when possible. To test for rescue, a $\mathrm{pCaSpeR}-\mathrm{Gtsl}$ insertion on the X chromosome was crossed into a $t s l^{691}$ mutant background. Females homozygous for $t s l^{691}$ and heterozygous for pCaSpeR-Gtsl were tested for fertility.

\section{Heat shock treatment and analysis of hs-tsl}

Healthy 4- to 5-day-old adults were heat-shocked for $1 \mathrm{hr}$ at $36^{\circ} \mathrm{C}$. The flies were allowed to recover for $10 \mathrm{hr}$ at $25^{\circ} \mathrm{C}$. Embryos were collected from 10 to $22 \mathrm{hr}$ after heat shock and aged for $30 \mathrm{hr}$ at $25^{\circ} \mathrm{C}$. For cuticle preparations embryos were dechorionated, and transfered to a drop of $50 \%$ lactic acid:50\% Hoyer's solution (Grigiatti et al. 1986) on a microscope slide, coverslipped, and baked at $65^{\circ} \mathrm{C}$ overnight.

\section{RNA preparations and Northern blot analysis}

Total RNA from embryos was prepared by homogenization in 6 $\mathrm{M}$ guanidine hydrochloride in $0.1 \mathrm{M}$ sodium acetate $(\mathrm{pH} 5.5)$, followed by centrifugation through a $5.7 \mathrm{M}$ cesium chloride cushion in $0.1 \mathrm{M}$ sodium acetate (pH 5.5), in a swinging bucket ultracentrifuge rotor at $25,000 \mathrm{rpm}$ for $18 \mathrm{hr}$ at $20^{\circ} \mathrm{C}$. Total RNA from ovaries was isolated by dissecting out ovaries from fattened females and homogenizing them in extraction buffer [50 $\mathrm{mm}$ Tris (pH 7.5), $10 \mathrm{~mm}$ EDTA, $100 \mathrm{~mm} \mathrm{NaCl}, 0.5 \%$ SDS] containing $400 \mu \mathrm{g} / \mathrm{ml}$ of proteinase $\mathrm{K}$. The RNA was extracted with phenol/chloroform, followed by chloroform, and precipited with $0.15 \mathrm{M} \mathrm{NaCl}$. Poly $(\mathrm{A})^{+}$RNA was isolated from the total embryo and ovary RNA, electrophoresed in a denaturing $1 \%$ agarose-formaldehyde gel, and transferred to GeneScreen Plus (NEN-DuPont) membrane. Membranes were hybridized in $50 \%$ formamide, $6 \times$ SSPE, $5 \times$ Denhardt's solution, and $0.1 \%$ SDS at $42^{\circ} \mathrm{C}$ overnight. The blots were washed in $0.1 \%$ SDS, $0.1 \% \mathrm{SSC}$, at $65^{\circ} \mathrm{C}$ for $2 \mathrm{hr}$.

\section{DNA sequencing}

DNA sequence was obtained using the Sequenase II kit (U.S. Biochemical). The 1.9-kb cDNA was sequenced on both strands using both dGTP and dITP to resolve compressions. Genomic DNA was sequenced using oligonucleotide primers derived from the cDNA sequence. The second intron was sequenced completely, but only the intron/exon boundaries were sequenced from the larger first intron. Most but not all genomic sequence was obtained from both strands. One nucleotide difference was observed between the cDNA and genomic sequences. Nucleotide 790 was found to be a $C$ rather than a $T$ in the genomic sequence, causing codon 84 to encode a proline rather than a leucine. The genomic sequence was confirmed in each of the five $t s 1$ strains sequenced. Therefore, it is likely that the cDNA sequence resulted from an error in reverse transcription.

\section{Acknowledgments}

We thank Dr. A. Spradling, in whose laboratory the $t s l^{0617}$ allele was generated, for his support. C. Andrews provided excellent technical assistance in cloning and DNA sequencing as well as in generating excision lines from $t s 1^{0617}$. We thank Dr. L. Stevens for providing $t s l$ stocks and for many helpful ideas and discussions and Dr. C. Montell for critical reading of the manuscript. D.J.M. is a Lucille P. Markey Scholar, and this work was supported in part by a Lucille P. Markey Scholar Award and in part by National Institutes of Health grant R29GM46425.

The publication costs of this article were defrayed in part by payment of page charges. This article must therefore be hereby marked "advertisement" in accordance with 18 USC section 1734 solely to indicate this fact. 


\section{Note added in proof}

The EMBL accession number for the sequence in Figure 5 is X75614.

\section{References}

Ambrosio, L., A.P. Mahowald, and N. Perrimon. 1989. Requirement of the Drosophila raf homologue for torso function. Nature 342: 288-291.

Casanova, V. and G. Struhl. 1989. Localized surface activity of torso, a receptor tyrosine kinase, specifies terminal body pattern in Drosophila. Genes \& Dev. 3: 2025-2038.

-. 1993. The torso receptor localizes as well as transduces the spatial signal specifying terminal body pattern in Drosophila. Nature 362: 152-155.

Cohen, B., M.E. McGuffin, C. Pfeifle, D. Segal, and S.M. Cohen. 1992. apterous, a gene required for imaginal disc development in Drosophila encodes a member of the LIM family of developmental regulatory proteins. Genes \& Dev. 6: 715729.

Degelmann, A., P.A. Hardy, N. Perrimon, and A.P. Mahowald. 1986. Developmental analysis of the torso-like phenotype in Drosophila produced by a maternal-effect locus. Dev. Biol. 115: 479-489.

Degelmann, A., P.A. Hardy, and A.P. Mahowald. 1990. Genetic analysis of two female-sterile loci affecting eggshell integrity and embryonic pattern formation in Drosophila melanogaster. Genetics 126: $427-434$.

Deng, H.-X., A. Hentati, J.A. Tainer, Z. Iqbal, A. Cayabyab, W.Y. Hung, E.D. Getzoff, P. Hu, B. Herzfeldt, R.P. Roos, C. Warner, G. Deng, E. Soriano, C. Smyth, H.E. Parge, A. Ahmed, A.D. Roses, R.A. Hallewell, M.A. Pericak-Vance, and T. Siddique. 1993. Amyotrophic lateral sclerosis and structural defects in $\mathrm{Cu}, \mathrm{Zn}$ superoxide dismutase. Science 261: 1047-1051.

Grigiatti, T., E. Hafen, P. Johnston, T. Jowett, M.G. Kidwell, P.A. Lawrence, M. Levine, G. Morata, C. Nüsslein-Volhard, M.L. Pardue, V. Pirrotta, D.B. Roberts, P. Santamaria, A.C. Spradling, E. Wieschaus, and M. Wilcox. 1986. Drosophila: $A$ practical approach. IRL Press, Oxford, UK.

Karpen, G. and A.C. Spradling. 1992. Analysis of subtelomeric heterochromatin in a Drosophila minichromosome Dp1187 by single P-element insertional mutagenesis. Genetics 132: 737-753.

King, R.C. 1970. Ovarian development in Drosophila melanogaster. Academic Press, New York.

Klingler, M., M. Erdelyi, J. Szabad, and C. Nüsslein-Volhard. 1988. Function of torso in deterining the terminal anlagen of the Drosophila embryo. Nature 335: 275-277.

Krantz, D.D., R. Zidovetzki, B.L. Kagan, and S.L. Zipursky. 1991. Amphipathic beta structure of a leucine-rich repeat peptide. J. Biol. Chem. 266: 16801-16807.

Lu, X., T.-B. Chou, N.G. Williams, T. Roberts, and N. Perrimon. 1993. Control of cell fate determination by $\mathrm{p} 21^{\text {ras }} / \mathrm{Ras} 1$, an essential component of torso signaling in Drosophila. Genes \& Dev. 7: 621-632.

Mlodzik, M., Y. Hiromi, U. Weber, C.S. Goodman, and G.M. Rubin. 1990. The Drosophila seven-up gene, a member of the steroid receptor gene superfamily, controls photoreceptor cell fates. Cell 60: 211-224.

Montell, D.J., P. Rørth, and A.C. Spradling. 1992. slow border cells, a locus required for a developmentally regulated cell migration during oogenesis, encodes Drosophila C/EBP. Cell 71: $51-62$.

Nishida, Y., M. Hata, T. Ayaki, H. Ryo, M. Yamagata, K.
Shimizu, and Y. Nishizuka. 1988. Proliferation of both somatic and germ cells is affected in the Drosophila mutants of raf pro-oncogene. EMBO I. 7: 775-781.

Nose, A., V.B. Mahajan, and C.S. Goodman. 1992. Connectin: A homophilic cell adhesion molecule expressed on a subset of muscles and the motoneurons that innervate them in Drosophila. Cell 70: 553-567.

Perkins, L.A., I. Larsen, and N. Perrimon. 1992. corkscrew encodes a putative protein tyrosine phosphatase that functions to transduce the terminal signal from the receptor tyrosine kinase torso. Cell 70: 225-236.

Perrimon, N. and M. Gans. 1983. Clonal analysis of the tissue specificty of recessive female-sterile mutations of Drosophila melanogaster using a dominant female sterile mutation Fs(1)K1237. Dev. Biol. 100: 365-373.

Perrimon, N., L. Engstrom, and A.P. Mahowald. 1985. A pupal lethal mutation with a patemally influenced maternal effect on embryonic development in Drosophila melanogaster. Dev. Biol. 110: 480-491.

Perrimon, N., D. Mohler, L. Engstrom, and A.P. Mahowald. 1986.X-linked female sterile loci in Drosophila melanogaster. Genetics 113: 695-712.

Rubin, G.M. and A.C. Spradling. 1982. Genetic transformation of Drosophila with transposable element vectors. Science 218: 348-353.

St. Johnston, D. and C. Nüsslein-Volhard. 1992. The origin of pattern and polarity in the Drosophila embryo. Cell 68: 201219.

Schupbach, T. and E. Wieschaus. 1986. Maternal-effect mutations altering the anterior-posterior pattern of the Drosophila embryo. Wilhelm Roux's Arch. Dev. Biol. 195: 302317.

Sprenger, F. and C. Nüsslein-Volhard. 1993. Torso receptor activity is regulated by a diffusible ligand produced at the extracellular terminal regions of the Drosophila egg. Cell 71: 987-1001.

Sprenger, F., L.M. Stevens, and C. Nüsslein-Volhard. 1989. The Drosophila gene torso encodes a putative receptor tyrosine kinase. Nature 338: 478-483.

Sprenger, F., M.M. Trosclair, and D.K. Morrison. 1993. Biochemical analysis of Torso and D-Raf during Drosophila embryogenesis: Implications for terminal signal transduction. Mol. Cell. Biol. 13: 1163-1172.

Stevens, L.M., H.G. Frohnhoffer, M. Klingler, and C. NüssleinVolhard. 1990. Localized requirement for torso-like expression in follicle cells for development of terminal anlagen of the Drosophila embryo. Nature 346: 660-663.

Strecker, T.R., S.R. Halsell, W.W. Fisher, and H.D. Lipshitz. 1989.Reciprocal effects of hyper- and hypoactivity mutations in the Drosophila pattern gene torso. Science 243: 1062-1066.

Tautz, D. and C. Pfeifle. 1989.A non-radioactive in situ hybridization method for the localization of specific RNAs in Drosophila embryos reveals translational control of the segmentation gene hunchback. Chromosoma 98: 81-85.

von Heijne, G. 1986. A new method for predicting signal sequence cleavage sites. Nucleic Acids Res. 14: 4683-4690.

Xu, T. and G.M. Rubin. 1993. Analysis of genetic mosaics in developing and adult Drosophila tissues. Development 117: 1223-1237. 


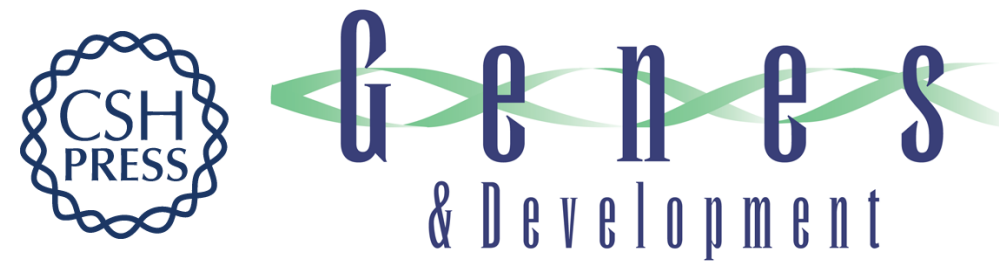

\section{torso-like encodes the localized determinant of Drosophila terminal pattern formation.}

S Savant-Bhonsale and D J Montell

Genes Dev. 1993, 7:

Access the most recent version at doi:10.1101/gad.7.12b.2548

References This article cites 30 articles, 12 of which can be accessed free at:

http://genesdev.cshlp.org/content/7/12b/2548.full.html\#ref-list-1

License

Email Alerting

Service

Receive free email alerts when new articles cite this article - sign up in the box at the top right corner of the article or click here.

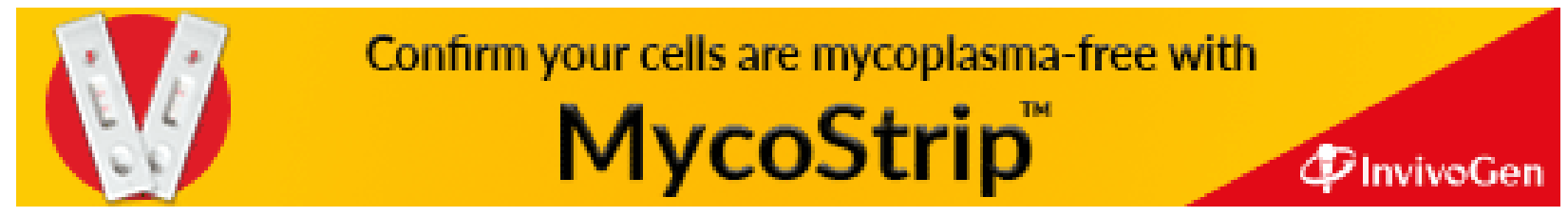

